\title{
MODEL KEMITRAAN PADA UMKM JAMU TRADISIONAL MADURA MELALUI PENDEKATAN ANALYTICAL HIERARCHY PROCESS
}

\section{PARTNERSHIP MODEL ON MADURA TRADITIONAL HERBAL MEDICINE SMES THROUGH THE ANALYTICAL HIERARCHY PROCESS APPROACH}

\author{
Yanuba Cahya Ramadhanti ${ }^{*}$, Resti Prastika Destiarni ${ }^{1}$, Dewi Muti'ah ${ }^{2}$ \\ ${ }^{1}$ Program Studi Agribisnis, Fakultas Pertanian, Universitas Trunojoyo Madura \\ ${ }^{2}$ Fakultas Hukum, Universitas Trunojoyo Madura \\ *E-mail: yanubacahya.ramadhanti@gmail.com \\ (Diterima 04-01-2022; Disetujui 27-01-2022)
}

\begin{abstract}
ABSTRAK
Kabupaten Pamekasan merupakan salah satu wilayah di Pulau Madura yang memiliki potensi dalam bidang produksi dan pengembangan jamu tradisional. Namun hingga kini, keberadaan UMKM jamu tradisional di Pamekasan berjalan secara individual dan berkembang menurut seleksi alam serta belum terdapat suatu kemitraan yang mewadahinya. Tujuan penelitian ini adalah menganalisis model kemitraan yang sesuai bagi UMKM jamu tradisonal Madura di Kabupaten Pamekasan. Metode yang digunakan dalam penelitian ini adalah Analytical Hierarchy Process (AHP). Hasil penelitian menunjukkan bahwa UMKM jamu tradisional di Kabupaten Pamekasan seluruhnya merupakan usaha dengan skala mikro. Sebagian besar pelaku UMKM jamu tradisional menyatakan belum memiliki kemitraan. Hasil analisis AHP menunjukkan bahwa model kemitraan jamu tradisional di Pamekasan dapat dibentuk melalui kriteria finansial dengan bobot 0.498 dan alternatif kriteria modal dengan bobot 0.394. Namun, kriteria-kriteria lain dalam hierarki juga perlu dipertimbangkan dalam menyusun model kemitraan UMKM jamu tradisional guna menyesuaikan dengan kondisi UMKM jamu tradisional di Pamekasan.
\end{abstract}

Kata kunci: kemitraan, UMKM, jamu, $A H P$

\section{ABSTRACT}

Pamekasan Regency is one of the areas on the island of Madura which has potential in the field of production and development of traditional herbal medicine. However, until now, the existence of traditional herbal medicine SMEs in Pamekasan has been carried out individually and developed according to natural selection and there has not been a partnership that accommodates it. The purpose of this study is to analyze the appropriate partnership model for traditional Madura herbal medicine SMEs in Pamekasan Regency. The method used in this research is the Analytical Hierarchy Process (AHP). The results showed that the traditional herbal medicine SMEs in Pamekasan Regency were entirely micro-scale businesses. Most of the traditional herbal medicine MSME players stated that they did not have a partnership. The results of the AHP analysis show that the traditional herbal medicine partnership model in Pamekasan can be formed through financial criteria with a weight of 0.498 and alternative capital criteria with a weight of 0.394 . However, other criteria in the hierarchy also need to be considered in developing a partnership model for traditional herbal medicine SMEs in order to adapt to the conditions of traditional herbal medicine SMEs in Pamekasan.

Keywords: partnership, SMEs, herbal medicine, AHP

\section{PENDAHULUAN}

Indonesia adalah Negara yang kaya akan keanekaragaman budaya. Salah satu dari keanekaragaman budaya tersebut adalah jamu tradisional yang telah digunakan oleh masyarakat Indonesia 
sejak berabad-abad tahun yang lalu. Indonesia sendiri memiliki lebih dari 9.600 jenis tumbuhan herbal yang dapat dimanfaatkan sebagai bahan dasar pembuatan jamu (Prabawa \& Fitriani, 2020). Jamu tradisional di Indonesia digunakan sebagai pengobatan tradisional yang dapat menjaga dan memelihara kesehatan serta mencegah dan mengobati berbagai penyakit. Pada mulanya jamu diracik dan dihidangkan dalam bentuk minuman rebusan yang kemudian dengan seiring perkembangan teknologi saat ini, jamu juga dikemas dalam bentuk serbuk ataupun kapsul sehingga dapat dikonsumsi dan disimpan dalam waktu yang lebih lama (Isnawati, 2021). Saat ini, jamu atau pengobatan tradisional telah diterima oleh beberapa Negara di dunia dengan menyebutnya sebagai alternatif maupun tambahan pengobatan medis (Siswanto, 2012).

Jamu menjadi resep turun menurun yang terus dipertahankan dan dikembangkan oleh masyarakat Indonesia. Bahan bahan jamu berasal dari tumbuhan alami seperti akar (rimpang), batang, daun, dan buah yang memiliki ragam manfaat diantaranya untuk menjaga kebugaran tubuh, menjaga kecantikan, serta mencegah dan mengobati penyakit (Sari, 2019).
Isnawati (2021) juga menyatakan bahwa bahan dasar yang digunakan dalam pembuatan jamu berasal dari tanaman herbal yang mudah didapatkan dilingkungan sekitar.

Madura menjadi salah satu daerah di Indonesia yang populer akan ramuan jamu tradisionalnya. Jamu tradisional Madura memiliki potensi untuk dikembangkan. Banyak masyarakat baik dari daerah Madura itu sendiri maupun luar Madura yang menyukai jamu tradisional Madura sebagai pengobatan herbal (Satriyati et al., 2019). Selain itu, Madura memiliki berbagai macam tanaman herbal yang membuat ramuan jamu tradisionalnya kaya akan rempah dan tanaman herbal lainnya yang memiliki ragam manfaat serta aroma yang kuat. Namun, dengan potensi yang dimiliki tersebut, tidak menjamin industri jamu tradisional Madura dapat berkembang baik. Hal tersebut dikarenakan adanya perkembangan zaman yang menyebabkan jamu tradisional harus bersaing dengan perusahaan-perusahaan jamu lainnya tingkat efisiensi yang berbeda serta manajemen dan peralatan yang lebih canggih dibanding industri jamu tradisional Madura. Adanya persaingan yang kuat dari perusahaan besar maupun 
pelaku usaha jamu lainnya mengharuskan UMKM jamu tradisional Madura untuk memiliki daya saing yang baik supaya mampu bertahan dan berkembang.

Kabupaten Pamekasan adalah salah satu wilayah di pulau Madura yang memiliki potensi dalam bidang produksi dan pengembangan jamu tradisional. Kabupaten Pamekasan diketahui sedang mengembangkan komoditas cabe jamu sebagai salah satu komoditas unggulan yang mana merupakan salah satu bahan dasar dari pembuatan jamu tradisional Madura. Selain itu, Pamekasan memiliki 13 kecamatan yang di setiap kecamatannya pasti memiliki usaha jamu tradisional dalam bentuk UMKM.

Berdasarkan UU No. 20 Tahun 2008, Usaha Mikro Kecil dan Menengah (UMKM) merupakan suatu usaha ekonomi produktif yang dimiliki oleh perorangan ataupun badan usaha milik perorangan dan bukan bagian dari anak cabang usaha besar atau perusahaan yang kemudian digolongkan menurut jumlah kekayaan bersih yang dimiliki serta hasil penjualan tahunan dari suatu usaha. UMKM berperan penting dalam pembangunan ekonomi Nasional melalui kontribusinya dalam menyediakan lapangan pekerjaan, pemerataan pendapatan serta kontribusi nyata dalam pertumbuhan ekonomi. Selain itu, dalam perekonomian di Indonesia, UMKM menjadi usaha dengan jumlah terbesar dan terbukti mampu bertahan dalam berbagai tantangan krisis ekonomi (Sedyastuti, 2018).

Fenomena Covid-19 menjadikan UMKM jamu tradisional Madura di Kabupaten Pamekasan semakin bertambah. Namun, keberadaan UMKM jamu di Pamekasan berjalan secara individual dan berkembang menurut seleksi alam. Hingga kini UMKM tersebut belum diwadahi oleh suatu kemitraan yang nantinya dapat menunjang eksistensi dan pengembangan usaha jamu tradisional supaya mampu memiliki daya saing yang lebih baik.

Kemitraan menurut UU No. 20 Tahun 2008 adalah suatu kerja sama usaha antar pelaku usaha mikro, kecil, menengah maupun usaha besar, baik secara langsung maupun tidak langsung dengan prinsip saling membutuhkan, saling percaya, saling menguatkan dan saling menguntungkan. Pintakami \& Asdasiwi (2020) mengemukakan bahwa kemitraan adalah perjanjian kerja sama dalam bentuk suatu lembaga antar pelaku usaha dari dua sektor atau lebih dalam rangka mendukung produksi dan/atau perlindungan terhadap barang. 
Kemitraan usaha dilaksanakan dengan beberapa macam pola, yang diantaranya; inti plasma, subkontrak, waralaba, perdagangan umum, distribusi dan keagenan, serta bentuk kemitraan lainnya seperti bagi hasil, kerjasama operasional, joint venture, dan outsourcing. Bagi suatu bisnis kemitraan usaha memiliki beberapa manfaat berupa efisiensi, produktivitas, peningkatan kualitas produk, pengurangan biaya produksi, pencegahan fluktuasi pasokan, pengurangan biaya penelitian dan pengembangan, serta peningkatan daya saing usaha (Widyani, 2013). Sementara manfaat yang dapat diperoleh dari kemitraan bagi suatu UMKM adalah (1) peningkatan produktivitas dan kreativitas, (2) efisiensi, (3) jaminan kualitas, kuantitas dan kontinuitas, (4) penurunan risiko kerugian, (5) menawarkan manfaat sosial yang cukup tinggi, (5) dan meningkatkan ketahanan perekonomian daerah (Shaferi \& Widiastuti, 2013).

Adanya kemitraan menjadi suatu upaya untuk membuat UMKM jamu tradisional Madura di Kabupaten Pamekasan menjadi lebih baik dan berkembang. Model kemitraan yang disusun merupakan hasil akomodasi dari segala faktor-faktor yang mendukung pengembangan usaha tanpa mengesampingkan preferensi individu dari pelaku usaha. Sehingga hasil dari kajian model kemitraan nantinya dapat digunakan oleh para pelaku UMKM maupun pemangku kepentingan lainnya dalam memperbaiki dan mengembangkan skala usaha dari UMKM jamu tradisional.

Berdasarkan uraian latar belakang yang telah disampaikan maka penelitian ini bertujuan untuk (1) mengelompokkan usaha jamu tradisional Madura kedalam kelompok usaha, mikro, kecil, dan menengah berdasarkan karakteristik dan (2) menganalisis model kemitraan yang sesuai bagi UMKM jamu tradisonal Madura di Kabupaten Pamekasan berdasarkan skala prioritas pilihan melalui Analytical Hierarchy Process.

\section{METODE PENELITIAN}

Penelitian dilakukan di Kabupaten Pamekasan dengan UMKM jamu tradisional sebagai objek penelitian. Sementara itu, responden UMKM yang dipilih dalam penelitian ini didasarkan pada metode judgement sampling. Populasi yang dipilih sebagai sampel dibatasi pada elemen populasi yang dapat memberikan informasi berdasarkan pertimbangan. Waktu penelitian dilaksanakan pada bulan September sampai bulan Desember 2021. 
Pendekatan yang digunakan dalam penelitian ini adalah penelitian kualitatif yang dianalisis dengan analisis deskriptif dan Analytical Hierarchy Process (AHP). Analisis deskriptif merupakan rangkaian informasi yang dapat berupa narasi yang disusun secara logis dan sistematis dan mengacu pada rumusan masalah penelitian (Akhmad, 2015). Dalam penelitian ini analisis deskriptif digunakan untuk memberikan suatu gambaran umum mengenai UMKM jamu tradisional di Kabupaten Pamekasan yang terdiri dari sejarah, perkembangan usaha, tantangan, masalah yang dihadapi, harapan dan model kemitraan yang diinginkan. Analisis deskriptif juga bertujuan untuk mengemukakan isu-isu strategis yang menunjukkan karakteristik UMKM jamu tradisional yang ada di Kabupaten Pamekasan serta kondisi internal dan eksternal UMKM.

Penelitian ini juga menggunakan pendekatan Analytical Hierarchy Process (AHP) yang merupakan suatu metode untuk memecahkan permasalahan yang kompleks tidak terstruktur menjadi beberapa komponen dalam susunan hierarki dengan memberikan nilai subjektif pada kepentingan relatif dari setiap variabel alternatif, serta menentukan variabel mana yang memiliki prioritas tertinggi dan dianggap terbaik sehingga nantinya akan mempengaruhi hasil akhir (Wardhana \& Prastawa, 2017). AHP digunakan dalam pengambilan keputusan seperti penentuan prioritas, pembuatan berbagai alternatif, pemilihan alternatif kebijakan terbaik, penentuan berbagai persyaratan, pengalokasian sumber daya, peramalan hasil dan penilaian risiko, pengukuran kinerja, perancangan sistem, perencanaan dan pemecahan konflik.

Dalam Wardhana \& Prastawa (2017), peralatan utama dalam AHP adalah memiliki sebuah hierarki fungsional dengan input utama berupa persepsi manusia bahwa dari masalah yang kompleks dan tidak terstruktur diselesaikan secara berkelompok dan kemudian ditransformasikan ke dalam hierarki. Hierarki itu sendiri didefinisikan sebagai suatu representasi dari masalah yang kompleks dalam suatu struktur multi-level yang level pertama adalah tujuan, diikuti oleh level selanjutnya yaitu faktor, kriteria, sub-kriteria, dan seterusnya hingga level terakhir dari alternatif (Darmanto et al., 2014). 


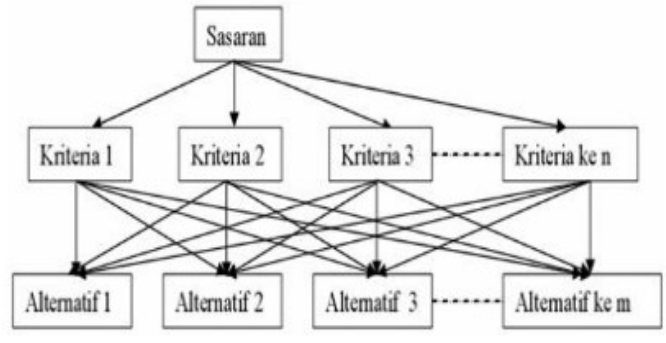

Gambar 1. Struktur Hierarki AHP

Analisis AHP dalam penelitian ini digunakan untuk menetapkan model kemitraan yang sesuai bagi UMKM jamu tradisional di Kabupaten Pamekasan. Setiap pelaku usaha memiliki preferensi dalam menentukan model kemitraan yang sesuai bagi usaha mereka. Pendekatan AHP akan memberikan pilihan model sesuai dengan skala prioritas berdasarkan keadaan UMKM jamu tradisional di Kabupaten Pamekasan.

\section{HASIL DAN PEMBAHASAN}

UMKM jamu tradisional Madura yang terdapat di Kabupaten Pamekasan ditemukan hampir di setiap penjuru Pamekasan baik UMKM yang sudah lama maupun yang masih baru. Sebagian besar UMKM jamu tradisional merupakan usaha turun temurun dari keluarga yang telah eksis selama puluhan tahun yang lalu. Namun, sebagian lainnya juga merupakan usaha sendiri yang mendapatkan pengetahuan mengolah jamu dari seorang guru maupun hasil belajar sendiri. UMKM jamu tradisional yang ditemukan dapat berupa usaha kios, gerobak dan gendong. Perkembangan usaha yang dilakukan oleh para pelaku UMKM masih dapat dikatakan minim karena para pelaku usaha diketahui banyak yang mengalami keterbatasan modal dan merasa cukup dengan menerima hasil seadanya serta kendalakendala lainnya. Secara keseluruhan, profil UMKM jamu tradisional di Kabupaten Pamekasan tersaji pada Tabel 1.

Berdasarkan hasil analisis dapat diketahui bahwa UMKM jamu tradisional di Kabupaten Pamekasan seluruhnya merupakan usaha dengan skala mikro. Hal tersebut dapat dilihat dari jumlah karyawan yang tidak lebih dari lima. Berdasarkan UU No. 20 Tahun 2008, hasil analisis keuangan juga menunjukkan bahwa UMKM jamu tradisional di Kabupaten Pamekasan tergolong dalam skala usaha mikro karena memiliki jumlah kekayaan bersih yang tidak lebih dari Rp 50.000.000,00 (lima puluh juta rupiah) serta hasil penjualan tahunan yang tidak lebih dari Rp 300.000.000,00 (tiga ratus juta rupiah). UMKM jamu tradisional di Kabupaten Pamekasan sebagian juga telah memiliki umur usaha yang lama, namun meskipun usaha tersebut telah 
lama berdiri, UMKM jamu tradisional masih tergolong dalam skala usaha mikro. Hal tersebut menunjukkan bahwa pengembangan yang dilakukan UMKM jamu tradisional masih sangat minim.

Tabel 1. Profil UMKM Jamu Tradisional di Kabupaten Pamekasan

\begin{tabular}{|c|c|c|}
\hline No & $\begin{array}{l}\text { Profil Usaha } \\
\text { Jamu }\end{array}$ & Keterangan \\
\hline 1. & Skala Usaha & \begin{tabular}{llr}
\multicolumn{2}{l}{ Seluruhnya } & hanya \\
memiliki karyawan $<5$ \\
orang yang 5 berarti \\
termasuk & skala & usaha \\
mikro & &
\end{tabular} \\
\hline 2. & $\begin{array}{l}\text { Kepemilikan } \\
\text { Izin Usaha }\end{array}$ & $\begin{array}{l}\text { Sebagian memiliki dan } \\
\text { sebagian tidak }\end{array}$ \\
\hline 3. & $\begin{array}{l}\text { Keikutsertaan } \\
\text { dalam } \\
\text { organisasi/ } \\
\text { perkumpulan }\end{array}$ & 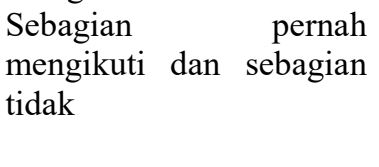 \\
\hline 4. & $\begin{array}{l}\text { Jenis Usaha } \\
\text { Jamu }\end{array}$ & $\begin{array}{l}\text { Terdiri dari usaha jamu } \\
\text { gendong, gerobak, dan } \\
\text { kios/toko }\end{array}$ \\
\hline 5. & $\begin{array}{l}\text { Jenis jamu } \\
\text { yang dijual }\end{array}$ & $\begin{array}{l}\text { Sebagian } \\
\text { merupakan jamu buatan } \\
\text { sendiri }\end{array}$ \\
\hline 6. & $\begin{array}{l}\text { Penggunaan } \\
\text { cabe jamu }\end{array}$ & $\begin{array}{l}\text { Sebagian menggunakan } \\
\text { cabe jamu dan sebagian } \\
\text { tidak }\end{array}$ \\
\hline 7. & $\begin{array}{l}\text { Tenaga kerja } \\
\text { yang dimiliki }\end{array}$ & $\begin{array}{l}\text { Sebagian besar pelaku } \\
\text { usaha jamu merupakan } \\
\text { pemilik sekaligus tenaga } \\
\text { kerja pengelola namun } \\
\text { beberapa ada yang } \\
\text { memiliki tenaga kerja } \\
\text { dari luar namun tidak } \\
\text { lebih dari } 5 \text { orang }\end{array}$ \\
\hline 8. & $\begin{array}{l}\text { Kemitraan } \\
\text { dengan usaha } \\
\text { lain }\end{array}$ & $\begin{array}{l}\text { Sebagian kecil memiliki } \\
\text { mitra dan sebagian besar } \\
\text { tidak memiliki }\end{array}$ \\
\hline 9. & $\begin{array}{l}\text { Kemitraan } \\
\text { dengan } \\
\text { pemasok }\end{array}$ & $\begin{array}{l}\text { Pelaku usaha jamu tidak } \\
\text { memilik kemitraan } \\
\text { dengan pemasok hanya } \\
\text { saja mereka langganan } \\
\text { pada satu pemasok }\end{array}$ \\
\hline 10. & $\begin{array}{l}\text { Teknik } \\
\text { Pemasaran }\end{array}$ & $\begin{array}{l}\text { Sebagian besar } \\
\text { menjualkan jamunya } \\
\text { secara langsung dan } \\
\text { sebagian kecil ada yang } \\
\text { memanfaatkan media } \\
\text { sosial }\end{array}$ \\
\hline
\end{tabular}

Pelaku UMKM jamu tradisional Madura di Kabupaten Pamekasan sebagian besar menyatakan belum memiliki kemitraan. Namun pada dasarnya UMKM tersebut telah melakukan suatu kesepatan tidak tertulis baik dengan pemasok maupun dengan distributor. Kemitraan yang terbentuk pada UMKM jamu tradisional meliputi kegiatan aspek produksi seperti pengadaan bahan baku dan fasilitas penggilingan, aspek pemasaran. Pelaku atau elemen yang terlibat dalam kemitraan usaha antara lain pemasok seperti petani maupun pedagang di pasar, penggilingan, kemudian distributor seperti pedagang di pasar, kios/toko, dan reseller. Kemitraan yang terjalin antara pihak UMKM dengan pemasok dan distributor hanya sebatas pada istilah "langganan" tanpa ada kesepakatan yang jelas apalagi tertulis. Secara alami pihak pihak tersebut menjadi pelanggan tetap satu sama lain.

Kemitraan yang terjalin antara UMKM jamu dengan pemasok berupa kegiatan produksi yaitu menyediakan bahan baku pembuatan jamu. Apabila pemasok kehabisan persediaan pihak UMKM jamu akan mencari pemasok lainnya sebagai pengganti sementara. Kemudian terdapat pelaku usaha 
penggilingan yang menyediakan fasilitas penggilingan untuk menghaluskan racikan jamu. Sementata itu, pola kemitraan yang terjalain antara UMKM jamu dengan distributor adalah dagang umum. Setiap produk yang dihasilkan akan dibeli ataupun di titipkan kepada pihak distributor. Namun, apabila distributor tidak dapat mendistribusikan produk dari UMKM jamu, maka pihak UMKM jamu berhenti mendistribusikan dan tidak pula mencari pengganti. Dari hal tersebut dapat diketahui bahwa pengelolaan usaha pada UMKM jamu tradisional Madura di Kabupaten Pamekasan dijalankan seadanya tanpa adanya kemitraan ataupun kesepakatan yang jelas.

Berdasarkan hasil temuan pada UMKM jamu tradisional Madura di Kabupaten Pamekasan tersebut, dibuat suatu pemecahan masalah atau kputusan untuk menentukan model kemitraan bagi UMKM jamu tradisional Madura dengan analisis AHP. Hasil diskusi dengan ahli/pakar serta hasil studi literatur diperoleh beberapa kriteria pada tiap level hierarki yang akan dimasukan dalam model. Pemodelan AHP disusun menjadi sebuah hierarki yang terdiri dari 3 level yaitu level utama sebagai tujuan hierarki, level kedua kriteria, dan level ketiga alternatif kriteria pemodelan kemitraan. Tujuan dari penyusunan hierarki model kemitraan jamu tradisional di Pamekasan adalah untuk memberikan kemudahan bagi MKM jamu dalam mengembangkan usahanya hingga menjadi lebih baik dan berkompeten. Hasil analisis AHP model kemitraan jamu tradisional Pamekasan dapat dilihat pada Gambar 2.

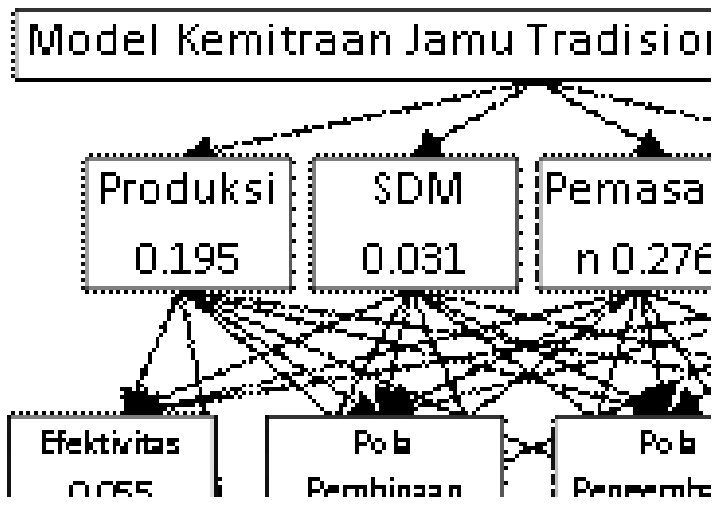

Gambar 2. Hierarki Model Kemitraan Jamu Tradisional Pamekasan

Hasil analisis di atas menunjukkan bahwa kriteria utama untuk menentukan model kemitraan jamu tradisional Pamekasan adalah kriteria finansial. Hasil pembobotan pada level kedua dalam menunjukkan finansial memiliki bobot tertinggi yang kemudian diikuti pemasaran dan produksi. Finansial merupakan kriteria penting dalam kemitraan UMKM jamu tradisional. Semakin tinggi akses terhadap finansial maka semakin besar pula peluang untuk mengembangkan UMKM (Amam et al., 
2019). Mitra finansial akan membantu maupun mempermudah persoalan keuangan UMKM jamu tradisional.

Kriteria lain yang tidak kalah penting dalam kemitraan UMKM jamu tradisional di Pamekasan adalah pemasaran dan produksi. Pemasaran menjadi hal penting dalam sebuah usaha guna memperkenalkan produk sekaligus usahanya kepada masyarakat luas (Imtihan \& Kardoyo, 2019). Adanya mitra pemasaran dengan pihak lain seperti distributor maupun pelaku UMKM lainnya akan membantu UMKM dalam kegiatan pemasarannya.

Kriteria terakhir yang juga menjadi pertimbangan dalam kemitraan UMKM jamu tradisional di Pamekasan adalah produksi. Adanya mitra produksi menunjukkan bahwa suatu usaha membutuhkan kerjasama dengan pihak lainnya guna membantu kelancaran proses produksi (Imtihan \& Kardoyo, 2019). Pihak-pihak yang dapat terlibat dalam kemitraan UMKM jamu di Pamekasan adalah pemasok dan usaha penggilingan.

Level ketiga dari model hierarki kemitraan UMKM jamu tradisional menunjukkan alternatif kriteria yang dipilih. Hasil pembobotan menunjukkan modal sebagai alternatif kriteria utama yang menentukan model kemitraan UMKM jamu tradisional. Hasil tersebut sejalan dengan penelitian Sunariani et al. (2017) yang menyatakan bahwa modal merupakan faktor utama yang menentukan prospek suatu UMKM. Modal menjadi alternatif kriteria utama yang membuat pelaku UMKM jamu tradisional di Pamekasan melakukan suatu kemitraan.

Alternatif kriteria lainnya yang juga menjadi pertimbangan untuk menentukan model kemitraan adalah pola pembinaan, pola pembinaan dari hulu ke hilir merupakan faktor akan berdampak pada prospek UMKM kedepannya (Sunariani et al., 2017). Selanjutnya terdapat pola pengembangan yang juga menjadi pertimbangan dalam model kemitraan jamu tradisional di Pamekasan. Kemitraan dengan pola pengembangan memberikan dampak positif seperti peningkatan produktivitas, peningkatan aliran investasi, memberikan kelancaran dalam distribusi dan pemasaran (Daraba et al., 2020). Alternatif kriteria lainnya yang perlu dipertimbangkan meskipun hasil analisis menunjukkan nilai bobot yang cukup kecil optimalisasi potensi, prosedur birokrasi, dan efektifitas.

Hasil analisis AHP secara keseluruhan menunjukkan bahwa model 
kemitraan jamu tradisional di Pamekasan dapat dibentuk melalui kriteria finansial dengan alternatif kriteria modal. Jasuni et al., (2018) menyatakan bahwa permodalan merupakan faktor yang paling penting untuk mengoptimalkan keuangan UMKM. Sehingga dapat dikatakan bahwa model kemitraan yang paling dibutuhkan oleh UMKM jamu tradisional di Pamekasan adalah kemitraan finansial dengan sistem permodalan.

\section{KESIMPULAN DAN SARAN}

\section{Kesimpulan}

UMKM jamu tradisional di Kabupaten Pamekasan seluruhnya merupakan usaha dengan skala mikro. Sebagian besar pelaku UMKM jamu tradisional menyatakan belum memiliki kemitraan. Namun pada dasarnya UMKM tersebut telah melakukan suatu kesepatan tidak tertulis baik dengan pemasok maupun dengan distributor. Hasil analisis AHP menunjukkan bahwa kemitraan finansial dengan sistem permodalan menjadi kriteria yang paling dibutuhkan oleh UMKM jamu tradisional di Pamekasan. Namun meskipun finansial dengan pilihan modal menjadi kriteria yang paling penting, kriteria-kriteria lain juga perlu dipertimbangkan dalam menyusun model kemitraan UMKM jamu tradisional guna menyesuaikan dengan kondisi UMKM jamu tradisional di Pamekasan dikarenakan setiap kriteria akan memberikan dampak positif terhadap pengembangan UMKM jamu tradisional.

\section{Saran}

Model kemitraan sebaiknya dibentuk dengan adanya keterlibatan aktor-aktor kemitraan, sehingga model yang terbentuk nantinya dapat benarbenar sesuai dengan apa yang dibutuhkan oleh UMKM jamu tradisional di Pamekasan. Dengan adanya model kemitraan dengan kriteria yang telah ditentukan tersebut, diharapkan nantinya dapat bermanfaat bagi pelaku UMKM jamu tradisional di Pamekasan dalam mengembangkan usaha.

\section{UCAPAN TERIMA KASIH}

Ucapan terima kasih kepada Program Studi Agribisnis Fakultas Pertanian serta Fakultas Hukum Universitas Trunojoyo Madura atas dukungannya dalam penelitian ini. Terima kasih juga disampaikan kepada pelaku UMKM jamu tradisional di Kabupaten Pamekasan yang telah 
memberikan informasi yang dibutuhkan dalam penelitian ini.

\section{DAFTAR PUSTAKA}

Akhmad, K. A. (2015). Pemanfaatan Media Sosial bagi Pengembangan Pemasaran UMKM (Studi Deskriptif Kualitatif pada Distro di Kota Surakarta). DutaCom Journal, 9(1), 43-54.

Amam, A., Fanani, Z., Hartono, B., \& Nugroho, B. A. (2019). Usaha Ternak Ayam Pedaging Sistem Kemitraan Pola Dagang Umum: Pemetaan Sumber Daya dan Model Pengembangan. Sains Peternakan, 17(2), 5-11.

Daraba, D., Murwani, S. I., Dione, F., \& Salam, R. (2020). Pola Prinsip Kemitraan Dalam Pengembangan Pariwisata di Kabupaten Purbalingga Provinsi Jawa Tengah. Profit: Jurnal Administrasi Bisnis, 14(2), 56-62.

Darmanto, E., Latifah, N., \& Susanti, N. (2014). Penerapan Metode Ahp (Analythic Hierarchy Process) Untuk Menentukan Kualitas Gula Tumbu. Simetris: Jurnal Teknik Mesin, Elektro Dan Ilmu Komputer, 5(1), 75-82.

Imtihan, S., \& Kardoyo, K. (2019). Kemitraan Produksi dan Pemasaran UMKM Sirup Mangga. Economic Education Analysis Journal, 8(1), 18-23.

Isnawati, D. L. (2021). Minuman Jamu Tradisional Sebagai Kearifan Lokal Masyarakat Di Kerajaan Majapahit Pada Abad Ke-14 Masehi. Ejournal.Unesa.Ac.Id, 11(2), 1-10.

Jasuni, A. Y., Firdaus, M., \& Sanim, B. (2018). Micro Financing Optimalization Strategy for MSMEs Development (Case Study at Kabupaten Bogor, Indonesia).
Indonesian Journal of Business and Entrepreneurship, 4(2), 161-169.

Pintakami, L. B., \& Asdasiwi, M. Y. (2020). Analisis Pola Kemitraan Agribisnis Di Kampung Kucai, Dusun Kranggan, Kecamatan Garum, Kabupaten Blitar. VIABEL: Jurnal Ilmiah Ilmu-Ilmu Pertanian, 14(1), 21-36.

Prabawa, H. W., \& Fitriani, A. D. (2020). Mempertahankan Eksistensi Jamu Tradisional melalui Perubahan Desain Pengemasan dan Pemasaran. DEDIKASI: Community Service Reports, 2(1), 35-46.

Sari, D. P. (2019). Analisis Usaha Jamu Tradisional (Studi Kasus: Ibu-Ibu Penjual Jamu Tradisional di Kelurahan Mabar Hilir). Universitas Muhammadiyah Sumatera Utara.

Satriyati, E., Biroli, A., \& Hana, S. N. (2019). Pilihan Rasional Perempuan Madura Dalam Pemertahanan Tradisi Minum Jamu Di Kabupaten Bangkalan Dan Sumenep. Jurnal Sosiologi Pendidikan Humanis, 4(2), 133141.

Sedyastuti, K. (2018). Analisis Pemberdayaan UMKM dan Peningkatan Daya Saing Dalam Kancah Pasar Global. INOBIS: Jurnal Inovasi Bisnis Dan Manajemen Indonesia, 2(1), 117127.

Shaferi, I., \& Widiastuti, E. (2013). Reorientasi Jaringan Pemasaran UMKM di Era Globalisasi dan Otonomi Daerah.

Siswanto, S. (2012). Saintifikasi Jamu Sebagai Upaya Terobosan Untuk Mendapatkan Bukti Ilmiah Tentang Manfaat Dan Keamanan Jamu. Buletin Penelitian Sistem Kesehatan, 15(2), 203-211.

Sunariani, N. N., Mahaputra, I. I. R., \& 
Suryadinatha, A. O. (2017). Pemberdayaan Usaha Mikro Kecil dan Menengah (UMKM) Melalui Program Binaan di Provinsi Bali. Jurnal Ilmiah Manajemen Dan Bisnis, 2(1), 1-20.

Wardhana, D. A. K., \& Prastawa, H. (2017). Analisis Pemilihan Supplier dengan Menggunakan Metode Analytical Hierarchy Process (Studi Kasus: UMKM Diana Bakery). EJournal Undip, 18(1), 39-46.
Widyani, W. M. (2013). Pentingnya Pola Kemitraan Dalam Rangka Meningkatkan Peran dan Kinerja Usaha Mikro, Kecil, dan Menengah di Jawa Timur Periode 2006 2011. Jurnal Ilmiah Mahasiswa Universitas Surabaya, 2(2), 1-12. 